水稲乳苗の初期生有に及ぼす除草剂の影響

一亩苗日数による差異および移植時の根切除処理の影響一

。住吉 正 $^{*}$. 伊藤一幸・橘雅明（東北農試）

乳苗（葉舲 $1.0 \sim 2.0$ 末満）による水稻移植栽培において, 除草剂による雑草防除法 確立のため苗の種類および移植時の条件に関して試驗を行った。

く材料および方法>

試験は1994年に東北農試水田利用部（秋田県大曲市）において行った。

水稻は品種「あきたこまち」を用い, 床土として水田土裹を使用し, 乳苗は4 日間 有苗(以後4 日苗と呼ぶ) と8 日間有苗 (同 8 日苗) の 2 種類とし, 4 日苗では乾籾 $250 \mathrm{~g} /$ 箱, 8 日苗では $200 \mathrm{~g} /$ 箱, 稚苗は $170 \mathrm{~g} /$ 箱播種した。いすれも播種後直苗器内 に $30^{\circ} \mathrm{C} て ゙ 48$ 時間出芽させた後, ハウス内で所定の日数有苗した（第 1 表）。供試した 除草剂は第 2 表に示した通りで，すへて寒冷地における標準使用量を処理した。

$1 / 5,000 \mathrm{a}$ ポットを用い，5月19日に上記水稲苗を植付け梁度 $1 \mathrm{~cm}$ と $3 \mathrm{~cm}$ の 2 段階 でポット当たり 5 本移植した。 8 日苗については, 移植時に根またはモミを完全に切 除した区を設け, 植付け梁度 $3 \mathrm{~cm}$ で移植した。なお, 植付け深度 $1 \mathrm{~cm}$ のものは苗を針 金で支えた。求 ットは雨よけハ ウス内に置き, 水深 $3 \mathrm{~cm}$, 無漏 水とし, 移植後 5 日目に各除草 剂を処理した。 除草剂処理後 3 週間日（6月 14 日) に抜き取っ て水稻の草丈, 葉制 (不完全葉 を含めない), 地上部乾物重等 を調查した。各 第 1 表 水稲苗の生育量

\begin{tabular}{|c|c|c|c|c|c|c|c|}
\hline \multirow[b]{2}{*}{7} & & \multirow{2}{*}{$\begin{array}{l}\text { 草丈 } \\
(\mathrm{cm})\end{array}$} & \multirow{2}{*}{ 葉 齢 } & \multicolumn{3}{|c|}{ 乾物重 $(\mathrm{g} / 100$ 本) } & \multirow{2}{*}{ 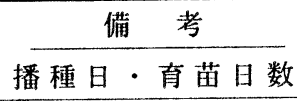 } \\
\hline & & & & 地上部 & モミ & 根 & \\
\hline 4 & & 4.0 & 0.3 & 0.22 & 1 & 0.08 & 5 月 15 日 · 4 日間 \\
\hline 8 & 苗 & 7.9 & 1.6 & 0.65 & 0.88 & 0.18 & 5 月 11 日・ 8 日間 \\
\hline 稚 & 苗 & 12.9 & 2.5 & 1.87 & 0.64 & 0.57 & 4 月 25 日 $\cdot 24$ \\
\hline
\end{tabular}

第 2 表 供試除草剂の有効成分含有量

\begin{tabular}{|c|c|c|}
\hline 除草剂名 & 有効成分含有量 & 処理量 \\
\hline (1) DPX-84 粒 & ベンスルフロンメチル $0.25 \%$ & \\
\hline (2) DPX-84 M 粒 & ジメピペレート 10.0\%,ベンスルフロンメチル $0.25 \%$ & \\
\hline (3) $\mathrm{NC}-311$ 粒 & ピラリ゙スルフロッエチル $0.07 \%$ & $300 \mathrm{~g} / \mathrm{a}$ \\
\hline (4) $\mathrm{NC}-311 \mathrm{~T}$ 粒 & ピラリ゙スルフロンエチル $0.07 \%$ メフェナセッ $3.5 \%$ & \\
\hline (5) $\mathrm{TH}-913$ 粒 & イマゾスルフロ\% $0.3 \%$ & \\
\hline
\end{tabular}

区 2 ポット。

く結果および考察〉

除草剂を処理しない区の水稻の生有は，植付け樑度による差はほとんどなく良好で あった(第 1 図)。根切除処理区では無切除区之同等の生育量であったが, モミ切除 処理区では無切除区に比べて乾物重で約 $36 \%$ 上回った（第3図）。

植付け深度と薬害との関係では, 苗の種類や除草剂の種類に関わらず, 植付け深度 Sumiyoshi T. , K. Itoh and M. Tachibana : Influences of Several herbicides on early growth of nursling rice seedlings. - Raising duration and root cutting * 現在, 九州農試 
$1 \mathrm{~cm}$ の方が $3 \mathrm{~cm}$ よも薬害が大き い傾向を示した。また，苗の種類 と薬害との関係は必ずしも明確で はなかったが，4 日苗および 8 日 苗の方が稚苗よりも薬害が大きい 倾向であった（第2図）。

根またはモミ切除処理と除草剂 の影響との関係では, 除草剂処理 条件下で根切除処理区の水稻地上 部重は無切除区に比べて減少傾向 を示したが, モミ切除処理区では 無切除区に比べて增加傾向を示し た（第 3 図）。この内, 根切除区 の N C - 311 T 処理では乾物重 の減少が大きく, 薬害が助長され た。また, モミ切除区の D P X 84 处理では薬害の症状が無切除 区よりも強く出た個体がみられた。 従って, 乳苗の機械移植におけ る根の切断やモミの脱落は, 植付 け樑度が $3 \mathrm{~cm}$ であっても除草剂の 種類によっては薬害が助長される 原因になるものと考えられた。

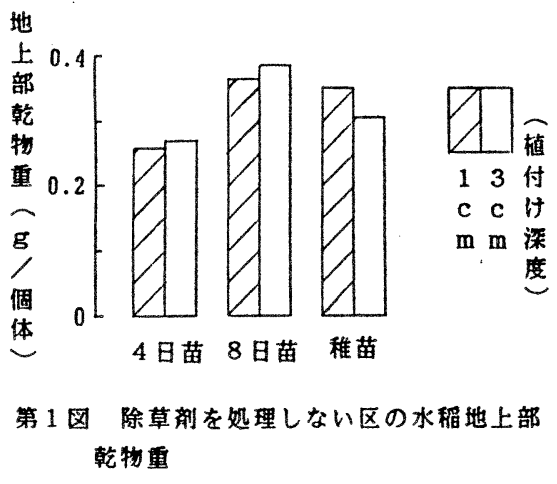

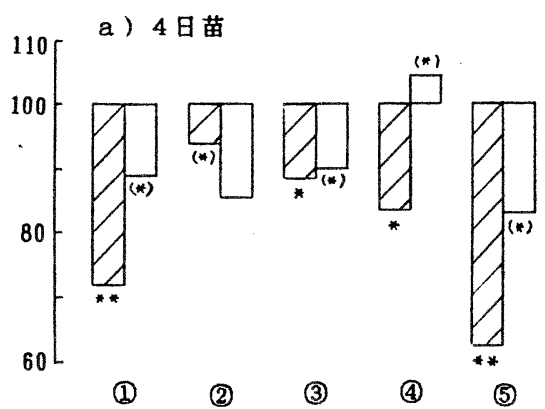

b） 8 日苗

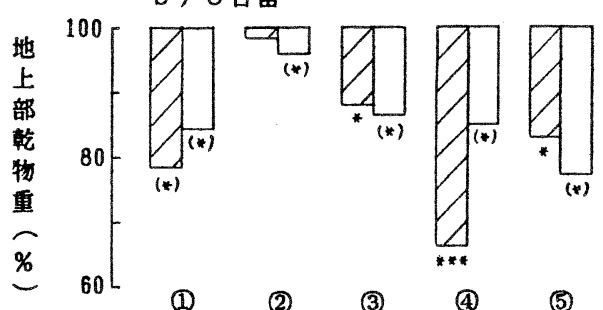

c) 稚苗

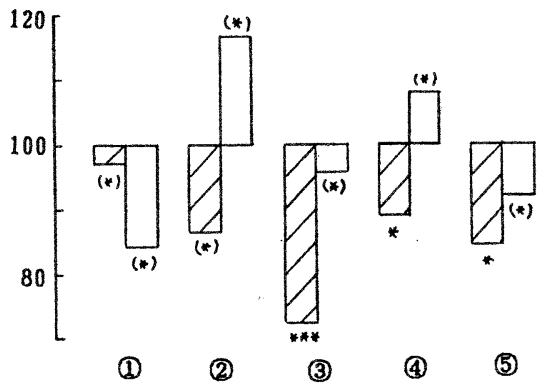

第2図苗の種類および植付け深度と除草郕の影との関係 注)地上部乾物重は除草刺無処理区に対する比事 (\%)。 (1)DPX-84, (2)DPX-84M, (3) NC-311, (4)NC-311T, (5)TH-913

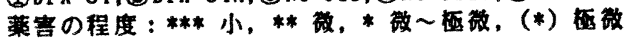
グラフの種類は第 1 図と同じ。

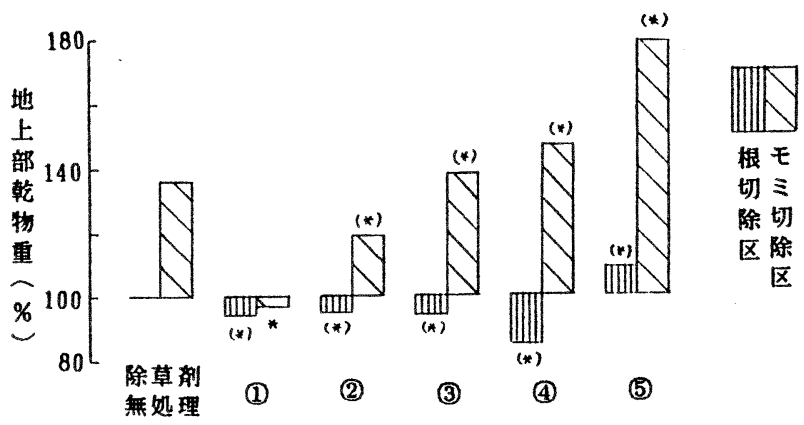

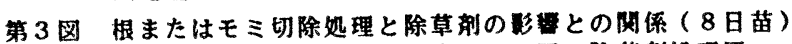
注) 地上部乾物重は植付け深度 3 c の同一除草绪処理区 に対する比事（\%)。

除草刜の種類、葙害の程度は第 2 因と同じ。 
スルホニルウレア系除草剤とシハロホップブチル等を混合した 剤の異なる水深におけるノビエの除草効果

。桶雅明・伊藤一幸・住吉 正（東北農試）

スルホニルウレア（ＳＵ）系除草剤はノビエを除くほとんどの水田雑草に長期的に 効果が高く、ノビエの 3 葉期までに使用する目的で、ノビエ専用剤としてのシハロホ ップブチル（DE H - 112）と混合している。茎葉処理型のシハロホップブチルと土 堙処理型の S U 剤を混合した粒剤の異なる水深における除草効果について調査した。

\section{<試験方法 >}

試験は1994年に東北農試水田利用部(秋田県大曲市)において行った。水稲は品種 「あきたこまち」を用いた。4月27日に耕起、整地、施肥（N, P, K : 各 $7 \mathrm{~kg} / 10 \mathrm{a} ）$ を行 い、5月13日に娄場内水深を变えるため、一方が低く、他方が高くなるように片側だ けから代かきを行った。5月17日に稚苗を機械移植し、1 週間浅水で管理した後、1 $\mathrm{cm} 、 6 \mathrm{~cm} 、 12 \mathrm{~cm}$ の各水深となるように設定した。かんがい水は排水溝よりポンプアッ プした。雑草はすべて自然発生で、ノビエはすべてタイヌビエであった。試験区の広 さは 1 区 $0.9 \mathrm{~m}^{2}$ (水稲 20 株) とし、 3 反復で行った。移植後 16 日目（2.5葉期）と 20 日 目 (3.0葉期) に表 1 に示した各除草剂を処理した。処理時、6月 23 日、9月 14 日にノビエの株数(茎数)、9月 6 日に除草剂試験区間の無除草の水深 $0 \mathrm{~cm} 、 3 \mathrm{~cm} 、 8 \mathrm{~cm}$ 、 $15 \mathrm{~cm}$ 区において晆間 $30 \mathrm{~cm} \times 90 \mathrm{~cm}$ の残草量を調査した。

\section{<試験結果 >}

水稲の活着まで各水深区とも浅水管理としたが、除草剤処理時のノビエの発生本数 は $1 \mathrm{~cm}$ 区で多く、12 cm区で少なかった。また、各水深区とも除草剤の処理日を同一日と したが、実際のノビエの最高葉格は表3の通りであった。ノビエの 2.5 葉期、3.0葉期に マークした個体はすべての試験区のすべてのプロットで枯死した。したがって、残草 したノビエは葉軨が 3.0 以上に進んでいたものであった。移植 37 日後のノビエ残存本数 は $1 \mathrm{~cm}$ 区において多いが、これは $1 \mathrm{~cm}$ 区の全処理と $6 \mathrm{~cm}$ 区の 3.0 葉期処理が効果発現中で あったことのよるもので、水深による除草効果の変動は 3 刘ともみられなかった(図1)。 また、3剂とも水稲に対する影䇾は観察されず、1 $2 \mathrm{~cm}$ 区における水稻の低收量は、围 場作成に伴う耕土層の減少のためと判断され、低収区は地力むらと雑草害によるもの であった(図2)。水深が異なるとノビエの葉路の進度が異なり、浅水区では葉秢の進 んだ個体の取りこほしがあり、収檴期の残存本数となってあらわれた。上からノビ 工を完全に抑制するには娄場を均平にし、より深い水深で管理することが適切である。 しかし、表4に示すように水梁15cmではクログワイ等は生育良好なため、これらの草 種について別途対策が必要である。

Tachibana, M., K. Itoh and T. Sumiyoshi : Activity of mixture with sulfonylurea herbicides and cyhal of op butyl on barnyardgrass as influenced by water depth. 
表 1 供試除草剂の有効成分含有率

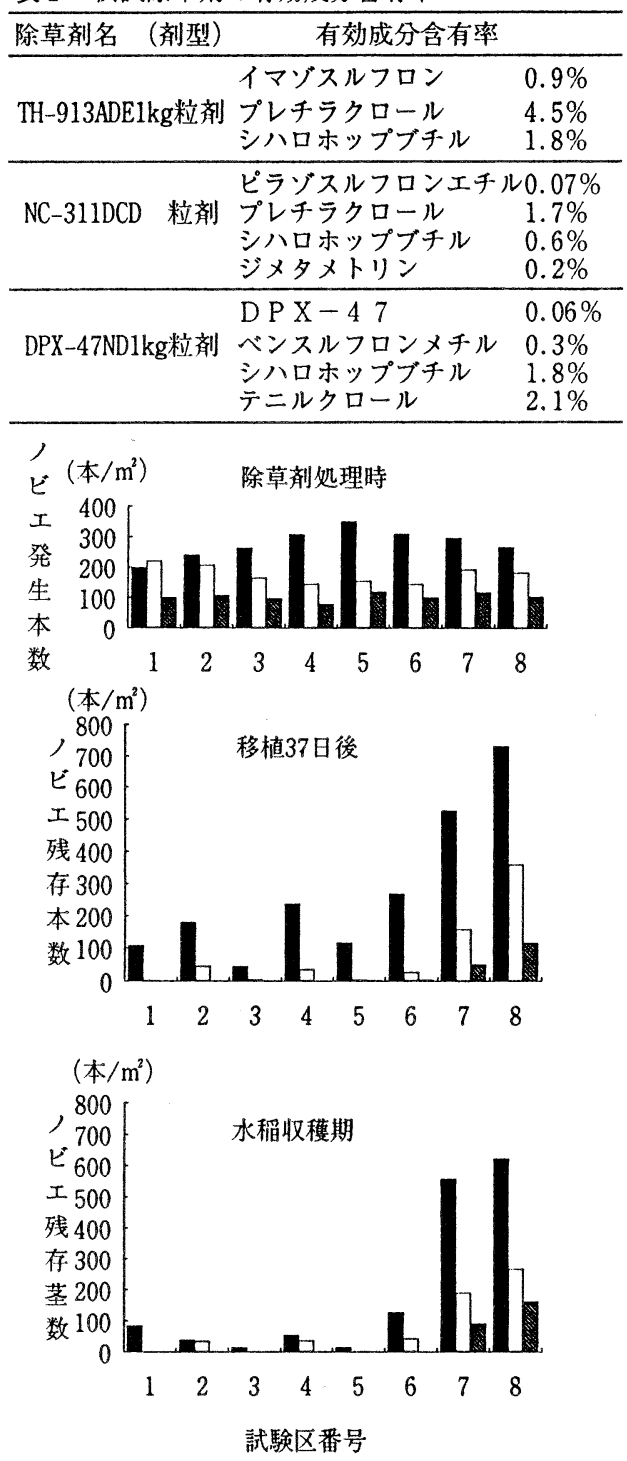

図1ノビエ個体数(茎数)の推移
表 2 試験区の構成と水稲への薬害

\begin{tabular}{clccc}
\hline $\begin{array}{c}\text { 試験区 } \\
\text { 番 号 }\end{array}$ & 除草剂 & $\begin{array}{c}\text { 処理時期 } \\
\text { (移植後日数) }\end{array}$ & $\begin{array}{c}\text { 使用量 } \\
(\mathrm{g} / \mathrm{a})\end{array}$ & $\begin{array}{c}\text { 水稲への } \\
\text { 影響 }\end{array}$ \\
\hline 1 & TH-913ADE1kg & +16 日 & 100 & なし \\
2 & TH-913ADE1kg & +20 日 & 100 & $" 1$ \\
3 & NC-311DCD & +16 日 & 300 & $"$ \\
4 & NC-311DCD & +20 日 & 300 & $"$ \\
5 & DPX-47ND1kg & +16 日 & 100 & $"$ \\
6 & DPX-47ND1kg & +20 日 & 100 & $"$ \\
7 & 無処理(2.5L) & - & - & - \\
8 & 無処理(3.0L) & - & - & - \\
\hline
\end{tabular}

表 3 処理時に最も進んでいた ノビエの葉齢

\begin{tabular}{rcc}
\hline 水深 & $2.5 \mathrm{~L}$ 期 & $3.0 \mathrm{~L}$ 期 \\
\hline $1 \mathrm{~cm} 区$ & 2.6 & 3.5 \\
$6 \mathrm{~cm}$ 区 & 2.5 & 3.2 \\
$12 \mathrm{~cm}$ & 2.1 & 2.5 \\
\hline
\end{tabular}

注)観察調査による

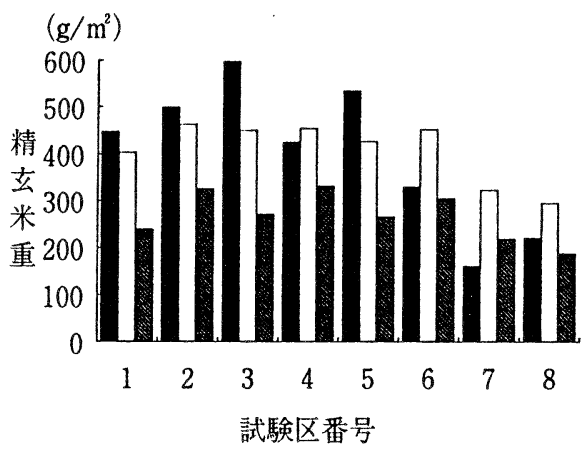

図 2 各区の水稲収量

水深： 1 $1 \mathrm{~cm}$ 口 $6 \mathrm{~cm}$ 区 $12 \mathrm{~cm}$ 区

表 4 試験固場の水深の差異と残草量(9月6日)および水稻収量

\begin{tabular}{l|cc|c|c|c|c}
\hline & $\begin{array}{c}\text { ノビエ } \\
\text { 水深 }\end{array}$ & $\begin{array}{c}\text { クログワイ } \\
\text { 茎数 }\left(\text { 本 } / \mathrm{m}^{2}\right)\end{array}$ & $\begin{array}{c}\text { その他 } \\
\text { 乾物重 }\left(\mathrm{g} / \mathrm{m}^{2}\right)\end{array}$ & $\begin{array}{c}\text { 合訃 } \\
\text { 乾物重 }\left(\mathrm{g} / \mathrm{m}^{2}\right)\end{array}$ & $\begin{array}{c}\text { 水稲収量 } \\
\left(\mathrm{g} / \mathrm{m}^{2}\right)\end{array}$ \\
\hline $0 \mathrm{~cm}$ & 1106.7 & 1363.7 & 0.0 & 0.0 & 1363.7 & 0.0 \\
$3 \mathrm{~cm}$ & 413.3 & 442.3 & 49.3 & 27.2 & 518.8 & 188.3 \\
$8 \mathrm{~cm}$ & 203.3 & 339.7 & 72.2 & 17.4 & 429.3 & 320.6 \\
$15 \mathrm{~cm}$ & 8.3 & 37.6 & 130.4 & 1.1 & 169.1 & 325.9 \\
\hline
\end{tabular}

注)全区とも無除草 
数種のスルフォニルウレア系除草剂のシズイに対する除草効果

清藤文仁（青森農試）

シズイはカヤツリグサ科の雑草で，昭和 54 年青森県上北郡で国内で初めて水田にお ける発生が確認された。その後, 北海道から東北。さらに新潟県などで発生が報告さ れている。防除法については，多くの娄場試験よりベンタゾン剤の卓効とスルフォニ ルウレア系除草剤の有効性が明らかとなっており,さらにベンフレセートの有効性も 報告（神名川ら 1992）されている。ここでは，平成 6 年度，青森農試での除草剤適用 性第 II 次試験において供試された数種のスルフォニルウレア系除草剂のシズイの除草 効果について，若干の知見を得たので報告する。

1. 試験方法

試験は青森農試直場で行った。土壌条作は多湿黒ボク土・壤土（減水深 $1.5 \mathrm{~cm} /$ 日） で耕起，入水及び代かきは，それぞれ，4月27日，5月4日及び5月7日であった。移植 は5月13日で稚苗機械移植とした。シズイの塊茎は, 場内養成娄場より4月下旬に採取 し, 冷温貯藏したものを耕起直前に播いた。供試薬郕は表 1 に示した。薬剂処理は除 草剂適用性第 II 次試験の試験設計に準じ, 雑草の拔き取り調查は7月22日（移植後70 日)に行った。

2. 結果の概要

1)本年のシズイの発生量は無除草区の全平均（風乾重）で $58.2 \mathrm{~g} / \mathrm{m}^{2}$, 発生本数は 232 本 $/ \mathrm{m}^{2}$ であった。

2) 処理時期が異なるがシズイに対する防除効果は, ベンスルフロンメチル（DPX-84） $0.25 \%$ 及び $0.75 \%$ 含有剤が高く，イマゾスルフロン（TH-913）含有剂がこれに続き， ピラソスルフロンエチル (NC-311) 含有剤は、これらより効果が劣った。DPX-84 (0.3\%)とDPX-47 (0.06\%)との混剂のDPX-47剂は早い処理では効果が劣り, さらにTH913 剂も粒剂の処理効果は安定しているが, フロアブル剂では+5処理で残草がかな り目立った（図 1)。

3)残存したシズイの個体当り風乾重は, 同時期処理のDPX-84殽よりも再発生が10日 ほど早めであったTDS-888フロアブル剂が重く、これと再発生の時期がほぼ同時期 であったTH-913剂の+3 +5処理では，発生後の抑制がみられ風乾重はやや軽めと なった（図 2 )。

4) 供試薬剂の除草効果について主成分分析を行ったところ，DPX-84郕はTDS-888フロ アブル剂を除き効果の安定性が高く、これに比べDPX-47剂は早い時期の処理で残 草が多かった。NC-311剤は再発生が目立ち明らかに効果が劣った。TH-913剂は早 い時期の処理で効果の变動が大きいが再発生後の抑制が強く，残草は小さめの個 体が多かった（図 3 ）。

5)処理時期による除草効果の変動は, 各剂とも処理が早いほど大きくなる傾向があ り、DPX-47剂，TH-913剂のフロアブル剂でこの傾向が強かった。 
表 1 供試薬剂

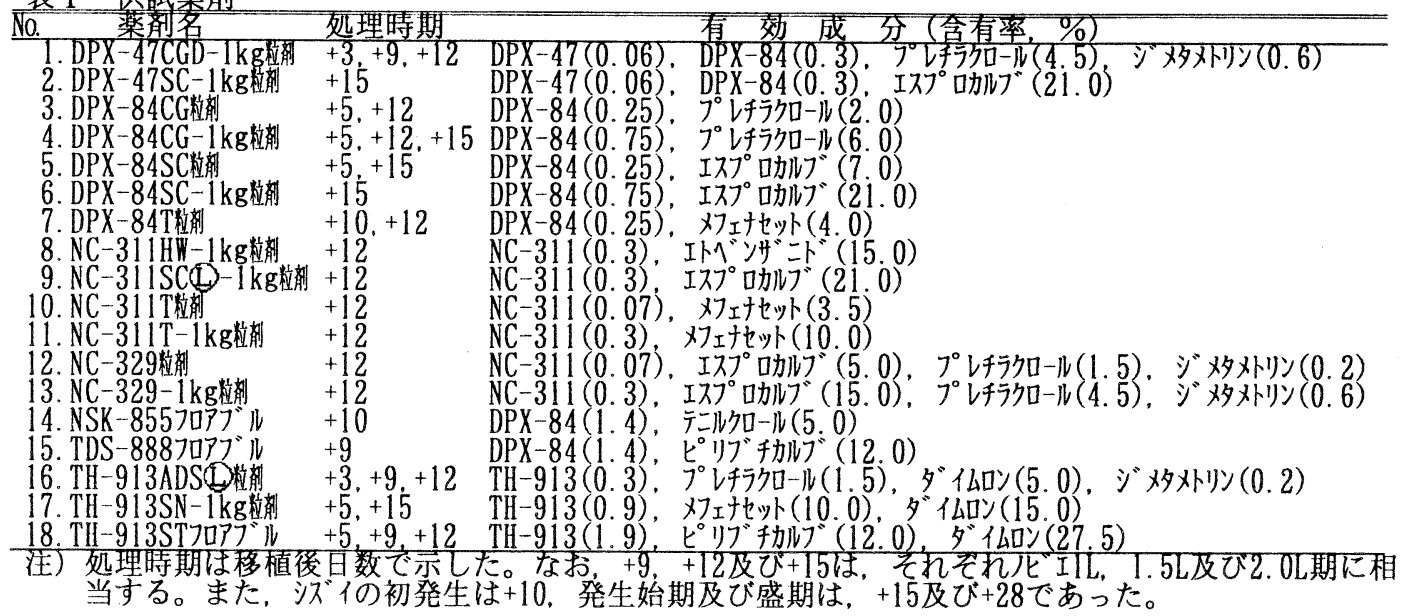
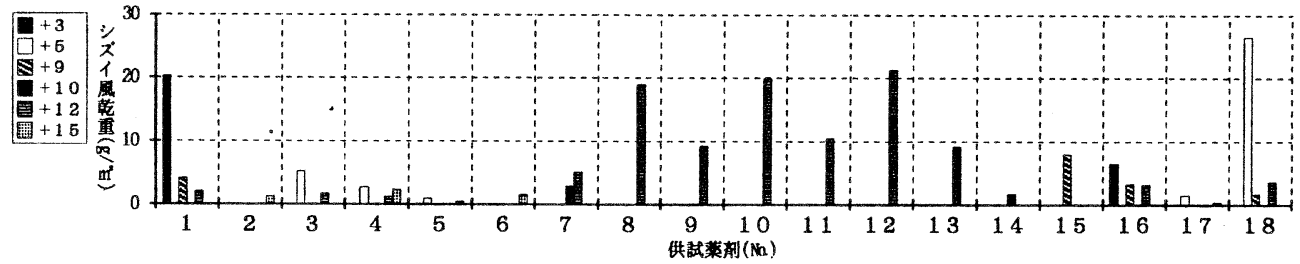

図1 シズイに対する除草効果（移植後70日）

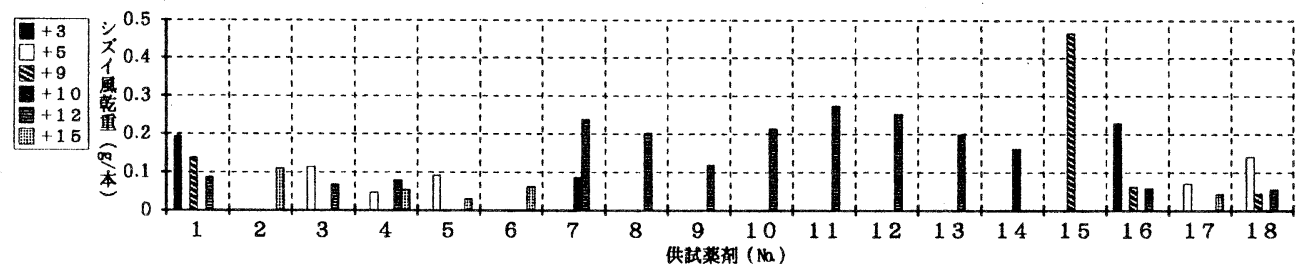

図2 シズイの個体当たり風乾重（移植後70日）

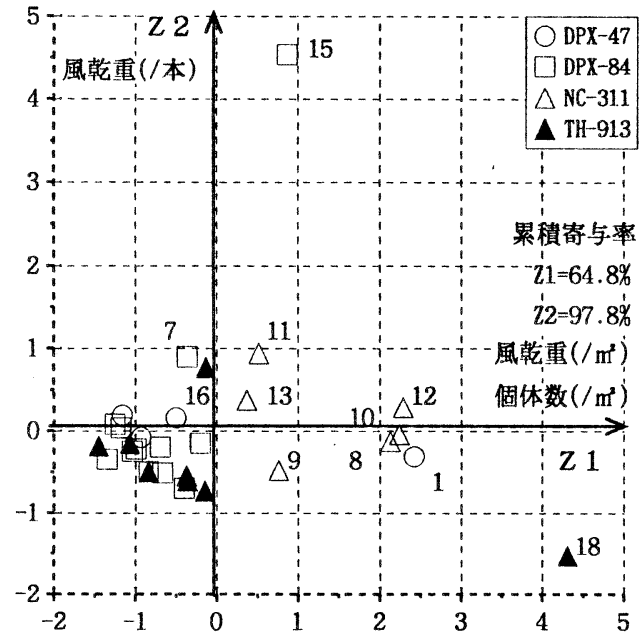

図3 除草効果の主成分分析

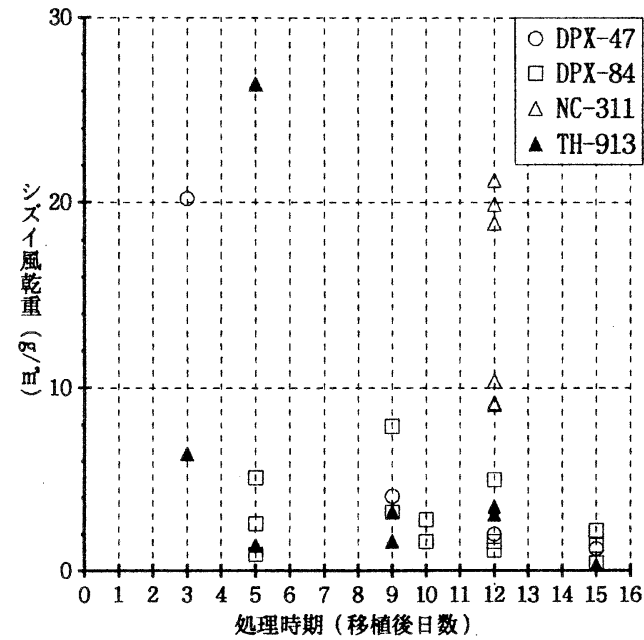

図 4 処理日別除草効果 
カヤッリグ科多年生雑草のシズイは、難防除雑草として東北各県で漸增している。シズィ

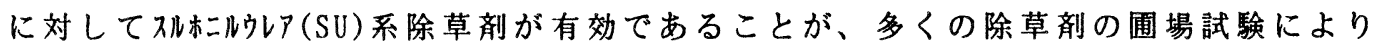
明らかにされてきた。ここでは、SU系の有効成分を含む除草剤について、シズ作対す る除草効果及び抑草期間の面から検討を行った結果を報告する。。

1 ）試験方法：1993年と1994年に宮城県古川農試及び岩手県立農試内のシズ㑑然発 生水田固場において、SU系除草剂の処理を行い、移植後約 40〜50日に残草量を調査し た。また、雑草の発生状況及び抑草期間は随時観察した。試験嘈場の条件等は第 1 表 のとおりで、供試した除草剤の成分名及び成分量は第 2 表のとおりである。ベンスルロン

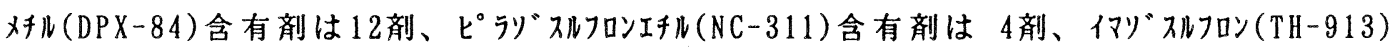
含有剤は 3 郕である。

2 ) 試験結果：1993年と 94 年の結果はほほ同様であったので、94年の結果を中心に 報告する。No 1 100、DPX-84を含有する $1 \mathrm{~kg}$ 粒剂(粒剂)の除草効果は、古川の移植 後 $(+) 41$ 日及び+52日調査では、無処理区対比でtrace $(t) \sim 3 \%$ の極大、岩手の+47日 調査では27〜 49\%の中〜小であった。しかし、抑草期間は№ 1〜 5の粒剂は古川で 27 〜30日であったのに対し、No6〜10の粒剤は30〜35日とやや長い傾向がみられた。こ れは、No 6〜10はDPX-84の成分量が0.75\%(10a当たり施用量 $7.5 \mathrm{~g})$ であるのに対し、 No 1〜 5は、DPX-47が含まれているとはいえ、DPX-84の成分量が $0.30 \%(10 a$ 当たり施 用量 $3 \mathrm{~g}$ )と低いためと考えられた。

また、No11及び12の、DPX-84含有のフ吅ブル(FL)郕の除草効果は、古川でそれぞれ 3 \%、2\%の極大であったが、観察ではN06〜10の粒剤より劣っていた。抑草期間も25 〜30日とNo 6〜10の粒剤より短い傾向がみられた。これは、DPX-84の成分量が $1.40 \%$ (10a当たり施用量 $7 \mathrm{~g})$ であることから、粒剤とFL剂の剂型の違いによるものではない かと考えられた。

No13〜16のNC-311含有の粒剂の除草効果は、古川では 2〜 $4 \%$ 極大で抑草期間も 35 日程度であった。しかし、観察ではNC-311系除草剤はDPX-84系除草剤より除草効果 はやや劣る傾向がみられた。また、同じNC-311含有剤のなかでも観察では、除草効果 はNC-329粒剂が一番高く、次にNC-311SC心粒剂でその次にNC-311HW粒剂と NC-311T粒 剂が同レベであった。これは混合されている他の成分の違いによるものと考えられた。

No17及び18の、TH-913含有の粒剂の除草効果は、TH-913ADS@粒剂は古川で 1\%の 極大、TH-913SN粒剂は岩手で36〜 103\%の中以下であった。また、No19のTH-913ST7口 アブル剤は古川で $1 \%$ の極大であった。しかし、TH-913系除草剤の抑草期間は、古川、 岩手とも前述のDPX-84系除草剂、NC-311系除草剂よりやや短い傾向にあった。

以上の結果から、SU系除草剂はシズ作対して有効であるが、有効成分の種類、成分 量、剂型の違いや、同一成分でも混合されている他の成分によって除草効果及び抑草 期間が異なることが明らかになった。なお、SU系除草剂のシズイに対する効果は高いが、 残草量が多い場合にはヘンン外ンを含む後期剤との体系処理が必要である。 
䈭1表 試験围場の条珄・シズイの発生状況等(1994年)

\begin{tabular}{|c|c|c|c|c|c|c|}
\hline 場所 & 土袞型 & $\begin{array}{l}\text { 減水深 } \\
(\mathrm{cm} / \mathrm{d})\end{array}$ & $\begin{array}{l}\text { 代搔き } \\
\text { (月日) }\end{array}$ & 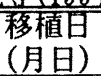 & $\begin{array}{l}\text { 除草剂 } \\
\text { 処理条件 }\end{array}$ & $\begin{array}{l}\text { 汉 1発生始期 } \\
\text { (移植後日数) }\end{array}$ \\
\hline III & 細粒強グライ土 & 0.5 & $5 / 09$ & $5 / 13$ & 湛水処理 & +5 \\
\hline 手 & 多湿黒ボク土 & 1.5 & $5 / 13$ & $5 / 18$ & 湛水処理 & +5 \\
\hline
\end{tabular}

\begin{tabular}{|c|c|c|c|}
\hline No & 試 験 名 & 成分名 & 成分量 $(\%)$ \\
\hline & DPX-47CGD-1kg粒剂 & 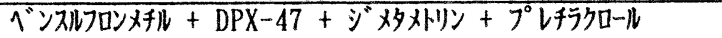 & $0.3+0.06+0.6+4.5$ \\
\hline 2 & DPX-47K-1 kg粒剂 & ベンスルフロンメチル + DPX-47+ベンチ抽ーブ + 对エナセット & $0.3+0.06+15+4.5$ \\
\hline 3 & $\mathrm{DPX}-47 \mathrm{MN}-1 \mathrm{~kg}$ 粒剂 & ベンスルコロンタチル + DPX-47+ジ北ペレート + ベンクレセート & $0.3+0.06$ \\
\hline 4 & DPX-47SC-1 kg粒剂 & 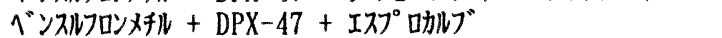 & 0.3 \\
\hline 5 & DPX-47TD-1 kg粒剤 & 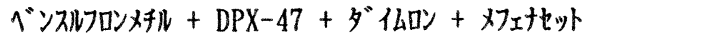 & $0.3+0.06+4.5+10$ \\
\hline & DPX-84CG-1kg粒剂 & ベンスルフロン妇ル +プレチラタロール & $0.75+6$ \\
\hline 7 & DPX-84MN-1 kg粒剂 & ベンスルフロンメチル + ジ北゚ペレート +ベンフレセート & $0.75+15$ \\
\hline 8 & DPX-84SC-1 kg粒剂 & ベンスルフロンメチル + エスプロ咖ブ & $0.75+$ \\
\hline 9 & -1kg粒剤 & ベンスルフロンメチル + メフェナセット & $0.75+$ \\
\hline 10 & KUH-883-1kg粒剂 & 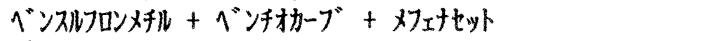 & $0.75+15$ \\
\hline 1 & NSK-855フロアブル剂 & ベンスルクロンメチル＋テニルクロール & $1.4+5$ \\
\hline 12 & TDS-8887ロ卫ブ剮 & 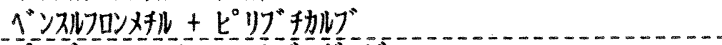 & $1.4+12$ \\
\hline $1 \overline{3}$ & NC-311 HW-1 kg粒剂 & 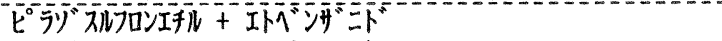 & $0.3+15$ \\
\hline 14 & NC-311SC(D-1kg粒剂 & ピラリ゙スルフロエエチル + エスプロ彻 & $0.3+21$ \\
\hline 15 & $\mathrm{NC}-311 \mathrm{~T}-1 \mathrm{~kg}$ 粒剤 & ピラヅスルフロンエチル +メフェ泤 & $0.3+10$ \\
\hline 16 & NC-329-1kg粒剂 & 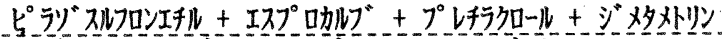 & $0.3+15+4.5+0.6$ \\
\hline 17 & DS(C)-1kg粒剂 & 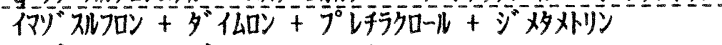 & $0.9+15+4.5+0.6$ \\
\hline 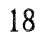 & TH-913SN-1kg粒剤 & 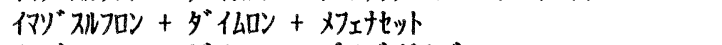 & $0.9+15+10$ \\
\hline & TH-913STフロアブル棛 & 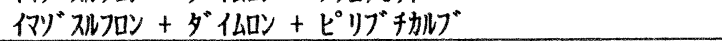 & $1.7+27.5+12$ \\
\hline
\end{tabular}

第3表 シズイに対する除草効果及び抑草期間

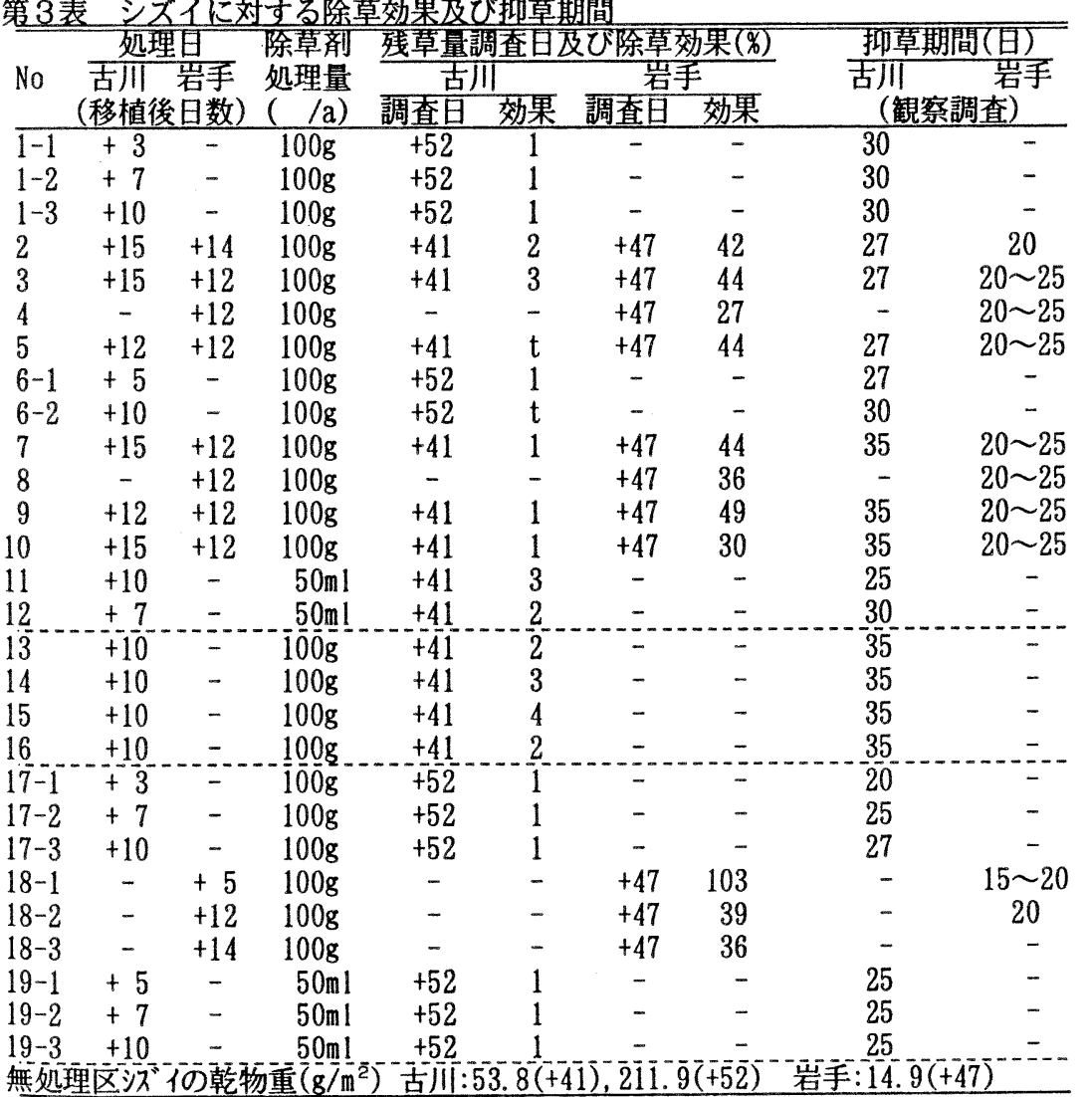

注) 除草効果の無処理区対比 1\%末満は、t(trace)とした。

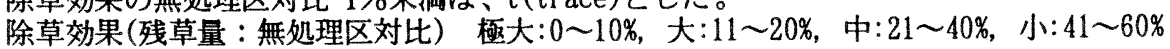


水稲乳苗に対する種々の除草剤の適用性

4. 植付深度の違いが生育に及ぼす影響

- 藤田笲・井口工・森芳史·三木 洋·片山哲治(香川農試)

前報において、乳苗と稚苗間には除草剂に対する感受性に差異があり、除草剤の種 類、処理時期及び育苗日数によってその程度が異なることを報告した。本報では、乳 苗の稙付深度を変えた場合の生育に及ぼす影響について㛟封を行ったので報告する。

〈材料及び方法〉

1)尔ット䧕験：1994年に1/5000a ワグネルポットで行った。供試品種は黄金晴、供試

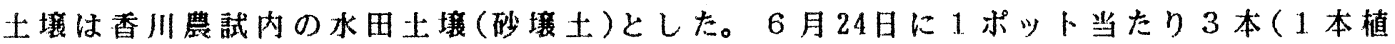
)を植付深度 $1 \mathrm{~cm}$ 及び $3 \mathrm{~cm}$ で移植した。供試苗は、7 日苗の乳苗(GN)、5 日苗の黄化乳 苗 $(Y N)$ 及び稚苗 $(T)$ とした。各苗の育苗方法及び移植時の苗䝷は第 1 表に示した。移

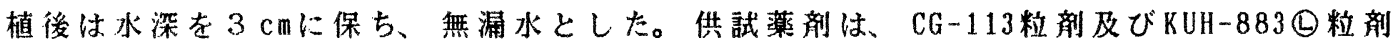
とし、再藻剂共に移植 5 日後に $300 \mathrm{~g} / \mathrm{a}$ を処理した。除草剂処理後 1 週間每に生育調查 (1区 3 個体 $\times 4$ 反復)を行い、移植 19 日後に堀取って生体重 ( 1 区 3 個体 $\times 1$ 反復)、 移植26日後には茎葉部と根部に分けて乾物重(1区3個体 $\times 3$ 反復)を科量した。

2 )固場試験：1994年に農試娄場（砂壤土）において行った。供試品種は黄金晴とし、6 月23日に浅植区として乳苗及び稚苗をそれぞれ植付深 $1.8 \pm 0.4 \mathrm{~cm}$ 及び $2.0 \pm 0.4 \mathrm{~cm}$ 、ま

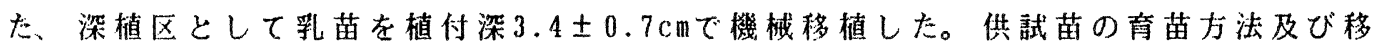

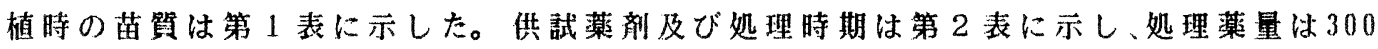
$\mathrm{g} / \mathrm{a}$ とした。除草剤処理後、経時的に生育調查と達観による薬害の観察調查を行い、成 熟期に1. $2.4 \mathrm{~m}^{2}$ を部分刈して收量調查を行った。調查はいずれも2 反復とした。

〈結果及び考察〉

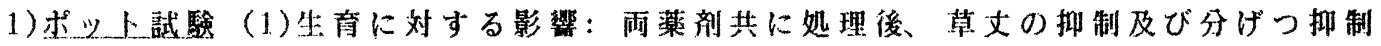
等の生育抑制が見られ、その程度は黄化乳苗>乳苗>稚苗の順に大きく、 $3 \mathrm{~cm}$ 植より 1 cm植区が大きい傾向があった(第 1 図)。

（2）生体重及び乾物重に対する影響：移植19日後の生体重及び移植26日後の乾物重の 無処理区に対する低下割合は、黄化乳苗>乳苗>稚苗の順に大きい傾问があり、また、 $3 \mathrm{~cm}$ 植より $1 \mathrm{~cm}$ 植区が大きい傾向にあった（第 3 表、第 2 四）。

2) 固場陚駼（1）生育に対する影響：SW-751粒郕区を対照とした焬合、供試したいすれ の薬剂区においても生育抑制が珰められ、その程度には薬剂間差が見られ、稚苗より 軋苗の方が大きかった。また、乳苗の浅植より深植の方が生育抑制が大きくなる傾向 が恝められたが、その程度も薬椷によって異なった(第4 表)。

（2）収量に対する影響：分げつ抑制の大きかった区では穂数も少なくなったが、収量は いずれの処理区においてもSW-751粒用区に比べて減収は認められなかった(第 4 表)。

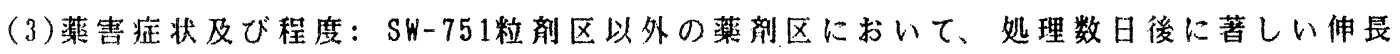
抑制を受けた個体が認められ、その発現阔体率は、稚苗より乳苗が高く、乳苗の中で は深植より浅植が高かった。その後、達観による菓害程度も同様の傾向で推移した。

以上より、除草戍による乳苗の薄害程度は、植付樑度を樑くすることによってその 程度は小さくなる傾向があった。しかし、ポット試験の正確な深植では薬害は著しく 軽減されるが、固埸の機械植ではその程度屿小さく、等の乳苗移植栽培では植付精 度の向上も必要であると考えられる。

Fujita,K.,T.Inoguchi,Y.Mori,H.Miki and T.Katayama:Applicability of several herbicides on rice nursling seedlings. IV . Effects of herbicides on the growth of rice transplanted in different planting depths. 


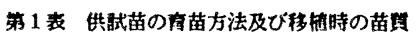

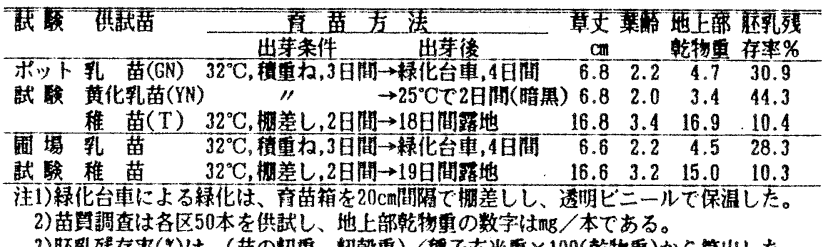

第 2 表 周場試駼における供試莱利及び処理時期

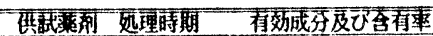

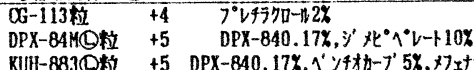

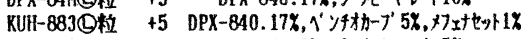

NC-329柆 +5 NC-3110.07\%, 7゚ レ459n-M1.5\%,

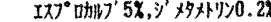

SW-751䊉 +3

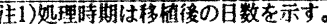

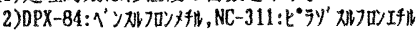

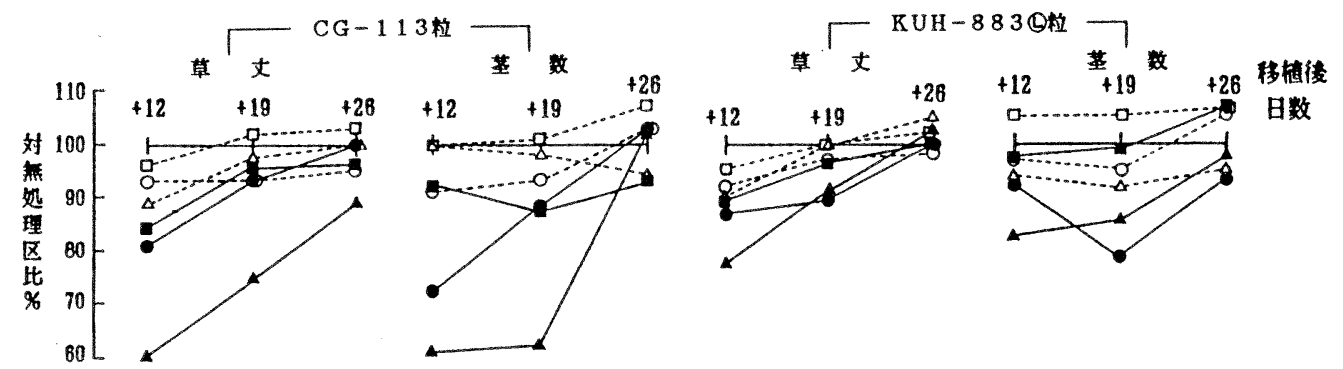

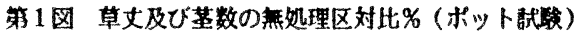

注) : 彶苗 $1 \mathrm{~cm}$ 植, $\Delta$ : 黄化䩐苗 $1 \mathrm{~cm}$ 植, 回: 稚苗 $1 \mathrm{~cm}$ 植

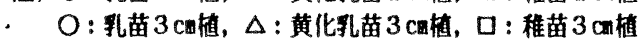

第3表 生体重の刑观理区対比\%

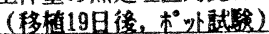

\begin{tabular}{|c|c|c|c|}
\hline \multirow{3}{*}{ 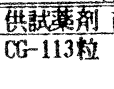 } & ब程 & 10 a & 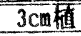 \\
\hline & $\mathrm{GN}$ & 52 & 88 \\
\hline & YN & 51 & 92 \\
\hline \multirow{2}{*}{ 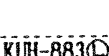 } & $\mathrm{T}$ & 91 & 93 \\
\hline & $\mathrm{GN}$ & 55 & 75 \\
\hline \multirow[t]{2}{*}{ 粒 } & YN & 42 & 79 \\
\hline & $\mathrm{T}$ & 77 & 83 \\
\hline \multirow[t]{3}{*}{ 処理 } & GN & $(11.0)$ & $(10.4)$ \\
\hline & YN & $(9.5)$ & $(9.3)$ \\
\hline & $\mathrm{T}$ & $(10.5)$ & (11.4) \\
\hline
\end{tabular}

注) 越理区のカッコ内の数字は

1 個体当りのg数を示す。

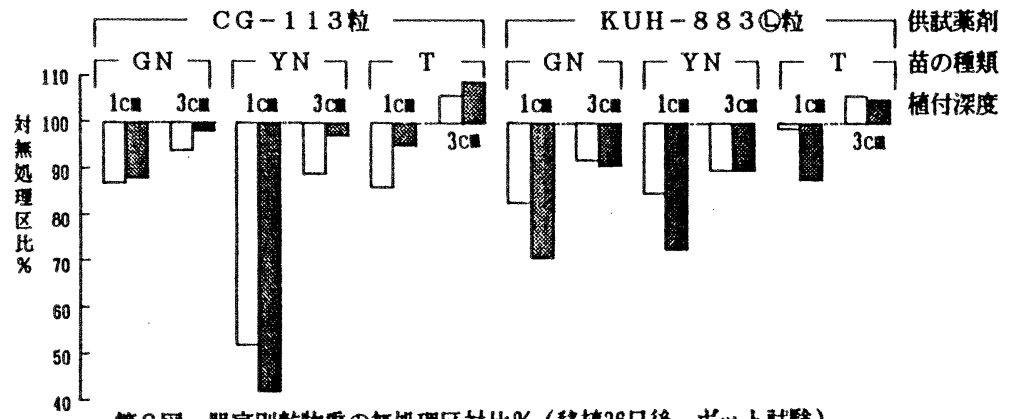

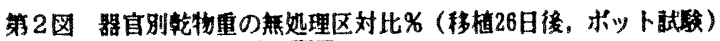

注1) $\square$ : 茎葉部, 鏭: 根 部

2) GN : 乳苗 (7 日苗)，YN：黄化乳苗（5日苗），T：稚苗（21日苗）

第4表 生育收量のSW-751粞剂区对比\%及び来害程度

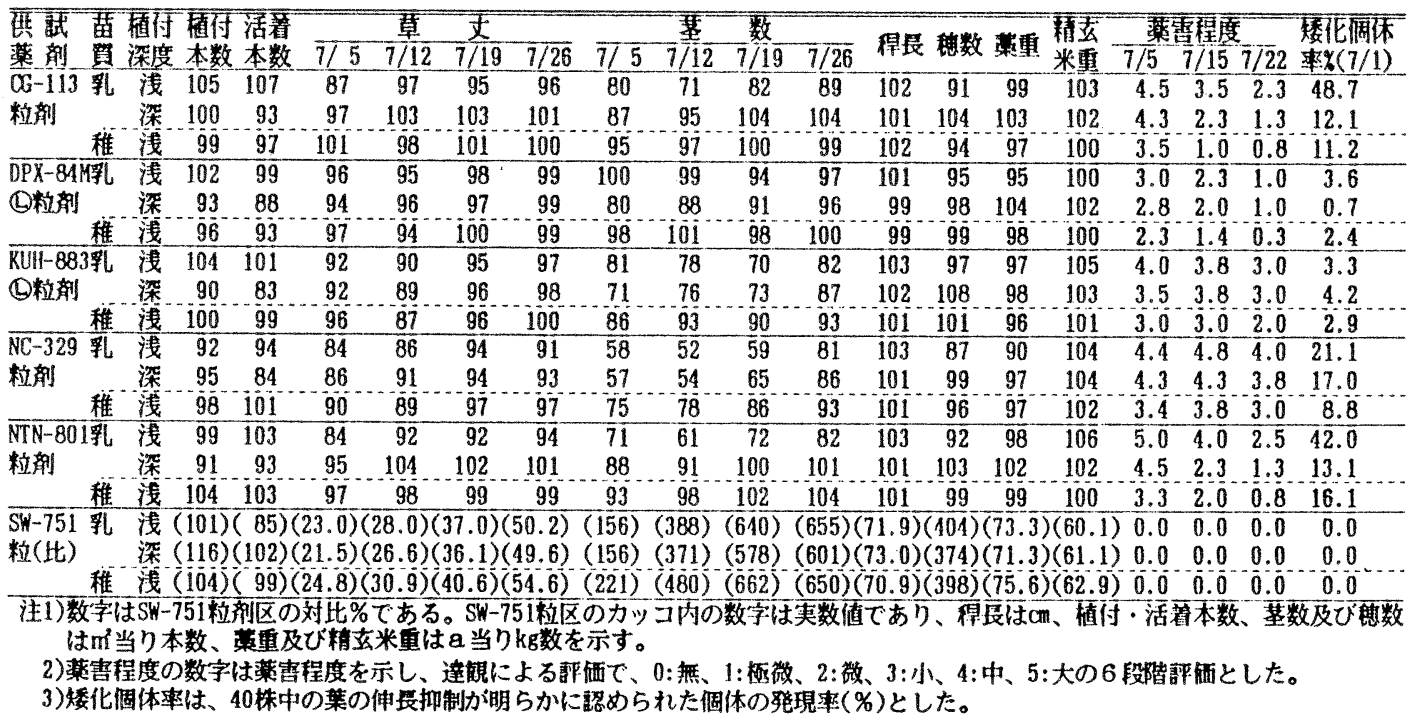

